of real women. While cultural representations may reflect and influence views of imprisonment, the responses of individual women often contradict traditional gender roles. As the authors observe in the epilogue, these women "have nuanced and complex relationships with the person in jail, other family members, society at large, and the institution of the prison" (201). The text also suffers from numerous stylistic and typographical errors, which detract from its valuable content. These points notwithstanding, this interesting study offers a multifaceted picture of the far-reaching consequences of the Russian Federation's inhumane prison system.

JULIE HANSEN

Uppsala University

\title{
Disrupted Idylls: Nature, Equality, and the Feminine in Sentimentalist Russian Women's Writing (Mariia Pospelova, Mariia Bolotnikova, and Anna Nau- mova). By Ursula Stohler. Trans. Emily Lygo. Slavische Literaturen: Texte und Abhandlungen 47. Frankfurt am Main: Peter Lang Academic Research, 2016. 357 pp. Appendix. Bibliography. Index. \$90.00, hard bound. \\ doi: 10.1017/slr.2018.178
}

This book examines Sentimentalism as a contradictory movement that, under the influence of Jean-Jacques Rousseau, limited women to the domestic, private sphere at the same time as women could develop "their" sphere as women, wives, and mothers into new areas of public, moral agency as published writers. This well-worn approach to women writers in Europe and America, by for example Jane Tompkins (1985), reframes national canons to include women. Building on Michelle Lamarche Marrese's work (2002), Ursula Stohler notes that unlike women elsewhere, Russian noblewomen had legal privileges that included ownership of land and serfs. Yet, they negotiated new cultural, moral norms that focused on their virtue and love, which were attractive, yet threatened to restrict their access to the public sphere (37).

With examples from French and English women's poetry, Stohler examines the different careers of three writers for their accommodations and challenges to Sentimental norms for women in both their poetry and its circulation and publication. In an appendix that is a real contribution to the field and a tribute to the seriousness of this series, Stohler includes eighteen excellent translations that aim for meaning, with Russian texts of the poems she analyzes. Especially the eleven poems by Anna Naumova complement Amanda Ewington's recent volume (2014) of fifty poems by seventeen women (but not Naumova) with English translations.

The first half of the book is diffusely argued around Rousseau's influence, in particular Émile's (1762) separate, unequal education for Sophie in virtue and obedience as wife and mother. Under the weight of a dissertation that strikes out into relatively new territory in Russian literature, Stohler ventures widely to reinvent the wheel and set up such related terms as nature, equality, public and private spheres, love, and virtue under the umbrella of a limited, literary view of Sentimentalism, which in fact engaged the greatest minds of the eighteenth century. Stohler does not question Rousseau's importance in an old European debate about women that long preceded him and continued after him (see Karen Offen's European Feminisms, 1700-1950: A Political History, 2000), and in Russia, which Thomas Barran's study (2002) shows was equivocal over Rousseau. The second chapter examines equality for women and serfs in the Russian context. There is an irony in representing noblewomen, who might own serfs, as Mariia Bolotnikova and Naumova's families probably did, as generic "women" who are, with serfs, oppressed. Lastly, Stohler summarizes how 
Russian women poets challenged key Sentimental ideas: 1) their virtues of goodness and religious belief overcome feminine modesty; 2) their poetic gift is spontaneous and they are like muses; 3) their Sappho is not a heartbroken suicide; and 4) their tributes to Antoinette du Ligier de La Garde Deshoulière's (1638-94) "Le ruisseau" (105, 178-79) re-envision the pastoral. Deliberately focusing on themes, Stohler ignores poetic genres, rhyme, and meter, which limits her analysis.

Based on the second half of this book and the appendix, one could argue that Mariia Pospelova, Bolotnikova, and Naumova-as befitting their ranks as the wives and daughters of (most likely) noble servitors to the emperor and the state in the era of the Napoleonic wars, like their French elite counterparts (see Carla Hesse, 2001)-ventured much further, into questions of emotions, reason, human nature and nurture in politics, philosophy, and pedagogy. Provincials, they engaged with Moscow literary life. From Vladimir, Pospelova (1780/83/84-1805) found protectors in the journal editor V.S. Podshivalov and her relative F.T. Pospelov, a translator and civil servant, who had worked for Gavriil Derzhavin. She caught the attention of Derzhavin, Mikhail Kheraskov, and Nikolai Karamzin when Paul I gave her a diamond ring for her ode to him (1796). Continuing to write odes, the highest civic poetic genre, she then dedicated her collection Luchshie chasy zhizni moi (1798) to Grand Duchess Elizaveta Alekseevna. From the Orel region, Bolotnikova, unknown even in bio-bibliographical dictionaries, published only a collection Derevenskaia lira, ili chasy uedineniia (1817), by subscription, thanking the local governor, Prince I.M. Dolgorukii, who mentions her in his memoirs (1874). Her poems are revelations: in "Uprek mushchinam," she calls on nature's "Holy law," or natural law (misinterpreted as an authoritative nature, 149) to give women "freedom" from men's oppression. In "Razsuzhdenie moego Dvoretskogo," "her" serf criticizes the master and mistress for living a refined life while neglecting their estate and serfs. Anna Naumova (1787-1862) left a Decembrist circle in Kazan, declaring herself a monarchist and retreating to her estate, where she educated nearly thirty wards on what amounted to an institutional scale, not unlike the Dowager Empress Maria Fedorovna, who then presided over institutes for noblewomen. She provided dowries and such poems as "Urok molodym devushkam," teaching them virtue and the dangers of men and love. These poems are in the Sentimental philosophical and pedagogical tradition of the monarchist Madame de Genlis, whose great treatise in letters on women's education in virtue and foreign languages, Adèle et Théodore (1782), was written against Émile and respected in Russia, unlike Rousseau's recipe of ignorant virtue. Russian noblewomen, like men, engaged fully with European Enlightenment Sentimentalism in all genres.

HILDE HoOgEnBoOM Arizona State University

Teksty-kartiny i ekfrazisy v romane Dostoevskogo “Idiot.” By Nina Perlina. Sankt Peterburg: Izdatel'stvo Aleteiia, 2017. Notes. Index. 288 pp. RUB 990, paper. doi: 10.1017/slr.2018.179

The role of western art in the composition and narrative of Fedor Dostoevskii's novel The Idiot has been well-studied; the role of ekphrasis somewhat less so. Nina Perlina's monograph Teksty-kartiny i ekfrazisy v romane Dostoevskogo "Idiot" is the first booklength study of ekphrasis in Dostoevskii's novel and of ekphrasis in a single novel in general. Perlina employs the trope to generate new readings of key visual moments in the text. The book presents an in-depth analysis of the pictorial scenes or what 